\title{
The Kreyol Reading Room
}

\author{
Paul C Mocombe* \\ West Virginia State University, The Mocombeian Foundation, Inc., USA
}

\begin{abstract}
The purpose of this work is threefold. First, using a structurationist approach, phenomenological structuralism, to understanding the constitution of society and practical consciousness, I argue that Haiti's current educational model is a colonial one, an ideological apparatus established by a French-speaking minority (comprador bourgeoisie), the mulatto elites and petit-bourgeois blacks, i.e., Affranchis, in order so that they can participate in the global (neoliberal) capitalist world-system as descendants of their former colonial administrators while the African majority are interpellated and subjectified as laborers for sports and the entertainment industries, tourism, and export agriculture and manufacturing jobs provided by the Affranchis, America, France, and Canada. Thus, in Haiti the attempt for a long time has been on following the black American bourgeois model of integration into the capitalist world-system by integrating the masses into the social class language game of their former colonial slavemasters (the French) at the expense of constituting their own social class language game based on the Kreyol language and Vodou metaphysics of the majority of the African inhabitants of the country. Second, I posit that in order to facilitate the latter, a second formal form of the Kreyol language, which distinguishes it (grammatically) from its spoken form, must be developed and institutionalized in schools for the purpose of scientific research, global discourse, and presentations. Lastly, I highlight Paul C. Mocombe's Kreyol Reading Room Series curriculum as a model for developing the latter process.
\end{abstract}

\section{Keywords}

Vodou ethic and the spirit of communism, Kreyol, Structurationism, Vodou, Dialectical, Anti-dialectical, Affranchis, Bois caiman, Boukman dutty, Phenomenological structuralism, Haitian epistemology, Haitian/Vilokan idealism

\section{Introduction}

Like the Africans of North America who were enslaved by the British, the Africans of Haiti were enslaved by the French on plantations to reproduce the colonial mercantilist system of global capitalism. Unlike the black American, which became a structurally differentiated black other (a racial-castein-class) in America. In Haiti, given that sixty-seven percent of the population where directly from Africa when the Haitian Revolution commenced in 1791, following the Haitian Revolution, many of the Africans were able to maintain and institutionalize their practical consciousness in the mountains and provinces of the island via the Kreyol language, the lakou system, and the Vodou Ethic and the spirit of communism [1-3]. Hence two opposing forms of system and social integration (i.e., social class language games), each with their own mode of production, language, ideology, ideological apparatuses, and communicative discourse, would constitute the Haitian social structure [1,3]. The Vodou Ethic and the spirit of communism of the Africans; and the Protestant/Catholic Ethic and the spirit of capitalism of the Affranchis, mulatto elites and petit-bourgeois blacks [1]. The latter, given their interpellation and embourgeoisement in European languages, mode of production, ideology, ideological apparatuses, and communicative discourse, sought to continue their participation in the global capitalist processes of the Europeans. The former sought to constitute an alternative form of system and social integration, i.e., a libertarian communal social class language game, by which they sought to interpellate and socialize the masses for subsistence living and sustainable development of the material resource framework over capitalist exploitation. Haiti's educational problematic, which is due to "a mismatch of linguistic structure and social class function," rests on the fact that these two opposing educational models developed in the country, each tied to the aforementioned forms of system and social integration. The elites (a comprador bourgeoisie) established a system for themselves based on the French educational model with its emphasis on literature, the arts and humanities, and foreign languages with French as the language of instruction [4,5]. This model was established at the expense of the African majority who were and are left uneducated in the latter system so as to fulfill their structural roles as tourist, agricultural, and factory laborers within the

*Corresponding author: Paul C Mocombe, West Virginia State University, The Mocombeian Foundation, Inc., USA

Accepted: November 10, 2020

Published online: November 12, 2020

Citation: Mocombe PC (2020) The Kreyol Reading Room. Insights Anthropol 4(2):297-302 
society for global capital. Conversely, the Africans established a system based on oral traditions, herbal medicine, and the ideology of Vodou with (oral) instruction in the Kreyol language. Lack of resources and the ideological apparatuses (i.e., laws, economic policies, etc.) and communicative discourse of the former system have undermined the development of the latter in favor of the former, which has led to the social, economic, and educational problematics of the people and the nation-state.

For me, in building on the theory of learning and development highlighted in Paul C. Mocombe's [6] structurationist theory of phenomenological structuralism, Haiti's educational system, given that as a homogeneous speech community, i.e., social class language game, dominated by Africans and the Kreyol language, should be tied to the development and codification of the grammar of the Kreyol language, the peoples' mode of subsistence agriculture, physics, psychology in particular and medicine in general, and socio-history with Kreyol as the language of instruction so as to constitute the society for subsistence living and the sustainable reproduction of the material resource framework. The latter processes constitute the fundamental basis of the lakou system and the Vodou Ethic and the spirit of communism. As it stands, however, Haiti's educational model is a colonial one, an ideological apparatus established by a French-speaking minority (comprador bourgeoisie), the mulatto elites and petit-bourgeois blacks, i.e., Affranchis, in order so that they can participate in the global capitalist world-system as descendants of their former colonial administrators while the African majority are interpellated and subjectified as laborers for sports and the entertainment industries, tourism, and export agriculture and manufacturing jobs provided by America, France, and Canada [3]. Thus, in Haiti the attempt for a long time has been on following the black American bourgeois model of integration into the capitalist world-system by integrating into the social class language game of their former colonial slavemasters (the French) as agricultural and technical workers at the expense of constituting their own social class language based on the Kreyol language and Vodou metaphysics of the majority of the African inhabitants of the country. In order for the latter process to take hold, however, the argument here is that two forms of the Kreyol language must be developed and institutionalized in the society: The pawol, spoken language of the people, must be distinguished from the lang, the formal (grammatical) form of the latter for schooling, scientific, and legal integration of the society. The Haitian Academy of Kreyol and the MIT Initiative under the direction of Michel DeGraff [5] have begun this formalization, which Paul C. Mocombe attempts to capture with his Kreyol Reading Room Series books, against the discriminatory practices and antagonism of the elites against the Kreyol language.

\section{Background of the Problem}

Traditional interpretations of the Haitian Revolution, and subsequent to that the constitution of Haitian identity, attempt to understand them, like the constitution of black diasporic and American practical consciousnesses, within the dialectical logic of Hegel's master/slave dialectic [2,3,7-10]. Concluding that the Haitian Revolution represents a struggle by the enslaved Africans of the island who internalized the liberal norms, values, and rules of their former French masters, for equality of opportunity, recognition, and distribution within and using the metaphysical discourse of their former white slavemasters to convict them for not identifying with their norms, rules, and values as recursively (re)organized and reproduced by blacks. Haitian identity/practical consciousness, as such, was and is a simulacrum, of European practical consciousness and identity, which is universalized and presented as the nature of reality as such. This position, predominantly held by white Westerners, is usually juxtaposed against the postmodern, post-structural, and postcolonial approaches of Haitian and other black bourgeois intellectual elites (i.e., Aimé Césaire), which highlight the hybridity, ambivalence, négritude, syncretism, indigénisme, and créolité, of the Revolution and Haitian practical consciousness [1].

Both interpretations, contrary to the position of Haitian intellectuals such as Jacques Roumain and Jean-Price Mars, who advised the Haitian intelligentsia class to look to the provinces and the peasant classes to constitute Haitian culture, identity, and nation-state, are problematic in that they are ethnocentric and racist. They both overlook the initial African practical consciousness of the majority of the Africans on the island for either the practical consciousness or discourse and discursive practices of the mulatto, Arab, and petit-bourgeois black elites, Affranchis, looking (because of their interpellation and embourgeoisement) to Europe, Canada, and America for equality of opportunity, recognition, and distribution, or for their (Affranchis) logic of postmodern, post-structural, and postcolonial theories to undermine that African presence in favor of notions of hybridity, créolité, négritude, syncretism, intersectionality, double consciousness, etc.

In their assumption of control of the state and its ideological apparatuses, i.e., schools, churches, police force, laws, military, etc., in other words, the Affranchis, as the whites before them, attempted to repress, "silence," through anti-superstitious laws to outlaw Vodou and economic policies to undermine its mode of production, the Vodou Ethic and the spirit of communism social class language game of the Africans for their own Euro-centered purposive-rationality, even though, paradoxically, many of them exercised aspects of the latter in secrecy $[3,9]$. Furthermore, their dialectical, postmodern, post-structural, and post-colonial textual productions, as seen in the works of Louis-Joseph Janvier, Thomas Madiou, Beaubrun Ardouin, Hérard Dumesle, and Anténor Firmin among many others, minimized and minimize the African structuring structure to highlight hybridity, créolité, négritude, ambivalence, and contradictions. In other words, they accentuate and substantiate the European practical consciousness as recursively reorganized and reproduced by whites, mulattoes, and petit-bourgeois blacks, but minimize the African in the ambivalence, creole, négritude, and hybrid language of postmodern, post-structural, and postcolonial discourses, which are still, dialectically, Western in origins and constitution.

\section{Theory and Method}

Essentially, the argument here is that there is no creole, 
négritude, ambivalent, hybrid, etc., consciousness by which Haitians of the nation-state reified and reify their social structure and went/go about recursively reorganizing and reproducing its ideas and ideals as their practical consciousness. My structurationist position, phenomenological structuralism, ultimately views identity, consciousness, and language development as the product of power relations within a structure, tied to the mode of production, which attempts to reduce human agency by forcing (via ideology, ideological apparatuses, communicative discourse, language, and the mode of production) actors to internalize its ideas and ideals and recursively (re)organize and reproduce them as their practical consciousness $[1,6,10]$. Hence social structure or a social class language game is a duality and dualism: Reified as a structure (dualism) via ideology, ideological apparatuses such as education and the family, communicative discourse, language, and mode of production whose concepts are in-turn internalized and recursively organized and reproduced (duality) as the practical consciousness of individual human actors.

Be that as it may, the assumptions inherent in this view are that: 1) Thought precedes language as a result of qualia, informational content or phenomenal properties, of psychions, which become embodied as a result of matter aggregation; 2) Languages of heterogeneous speech communities are emergent in the cerebral cortex of the embodied brain, and attempt to capture the nature of reality as such through syntax or generative grammar and the language games of those who control the resources of a material resource framework; 3) The signs (signifier and signified) of the language games of those who control the resources of a material resource framework are arbitrary; 4) Two linguistic systems emerge and dominate heterogeneous speech communities, the ordinary language of a speech community and the language of science/religion, which attempts (through experimentation, formalization, and systemization) to capture the nature of reality as such by which members of speech communities must recursively reorganize and reproduce their being-in-the-world through their generative grammar and speech acts; and 5) Ordinary languages are conventional and rule governed based on the rules of the social class language game of those who control the resources of a material resource framework and not necessarily the language of science/religion, which is also rule-governed but in relation to the nature of reality as such.

Hence in phenomenological structuralism the reading is that consciousness is the by-product or evolution of subatomic particles, psychions, unfolding, as qualia (subjective informational content), with increasing levels of abstraction within an evolutionary material resource framework enframed by the mode of production, language, ideology, ideological apparatuses, and communicative discourse, i.e., social class language game, of bodies (who control the material resource framework) recursively reorganizing and reproducing the language and ideals (conventions) of the latter factors as their practical consciousness or activity. Within this perspective, thought precedes language as a result of conflict and the phenomenal properties, qualia, of embodied subatomic particles, which direct action in an emergent material world via impuls- es or drives. (Ordinary) language is an emergent system generated from an innate structure of the embodied brain in order that we can be in the world, communicate, and do things with the other things and beings we experience the world with for our survival. Thus, in phenomenological structuralism the understanding is that the structure of reality determines language (via its generative grammar) and how we ought to live and do things in the world for our survival amidst the internal thought processes of phenomenal properties, qualia, of psychions of individuals. However, the (ordinary) language, and its usage, i.e., social class language game, of those who control the material resource frameworks of the world conceals that relationship (the relationship between the individual and the structure of reality as such) via their mode of production, language, ideologies, ideological apparatuses, and communicative discourse (ordinary language), which is evolutionary. In other words, like the Wittgensteinian position of the Tractatus, Mocombe's theory of phenomenological structuralism assumes that there is a uniform (grammatical/syntactical) structure to language determined by the logical-empirical structure of (quantum and physical) reality. The grammatical structure of linguistic utterances and sentences attempt to capture the subjects, objects, and states of affairs of that reality and how we ought to live in it and among them for our survival. In being-in-the-world with others, this logical-grammatical structure, however, is concealed by the evolution and developmental knowledge, and its usage (practical activity), of those who control the material resource framework of the world via the stage of development of their language, ideology, ideological apparatuses, social relations of production, and communicative discourse (ordinary language). Be that as it may, the latter comes to constitute an evolutionary social class language whose linguistic systemicity and usage comes to determine our conception of reality, and the classes, categories, and forms of life we belong to and interact in and with, which depending on its stage of development and relation to the True nature of reality as such, is either accepted or constantly deferred by those individuals in its speech community who are marginalized or not represented in its evolutionarily developed linguistic systemicity. The latter process under the guise "language game," language as a tool, is what Wittgenstein captures in his second treatise on language as developed in the Philosophical Investigations. That is, the classes and categories created by the dominant social class language game of a material resource framework, in their efforts to capture the logical-grammatical structure of reality and how we ought to live within it, constitute reified classes, categories, and forms of life, "language games," whose meanings and praxes as defined by the dominant social class language game are either accepted or deferred by those individuals classified in them (based on their 1) Qualia, 2) Drives of the body, or 3) Their abilities to defer meaning in ego-centered communicative discourse). The latter may in-turn seek to reify their form of life that they are marginalized for, or categorized in, as a distinct alternative practical consciousness or heterogeneous community to that of the dominant order thereby undermining the attempted universality of the logical-grammatical structure of the dominant order for notions of diversity, intersectionality, etc. 
So in Mocombe's theory of phenomenological structuralism, Wittgenstein's two theories of language and meaning must be read as one philosophy as opposed to two, one supported by analytical philosophy and the other by postmodernism/post-structuralism. We have a plethora of (ordinary) language games (classes, forms of life, and categories), heterogeneous speech communities, in the world, which structures our language, because of the ability to defer meaning in ego-centered communicative discourse and the developmental stage of the human mind and body vis-à-vis the actual structure of reality. The language of science, like its predecessor religion, attempts to capture the "True" logical-empirical structure of (quantum and physical) reality, and how we ought to live within it, amidst the (ordinary) utterances and practical consciousnesses of the masses given their abilities to defer meaning in ego-centered communicative discourse and the classes, categories, and forms of life they are classed in/with by the dominant social class language game as they attempt to be in the world via their (ordinary) language.

\section{Discussion}

Applying Mocombe's philosophy of language as presented in his theory of phenomenological structuralism to the Haitian case, the logic here is that Haitians, the minority Affranchis, are interpellated in one of the two aforementioned social structures (social class language games) and either recursively reorganize and reproduce as an "other" the ideas and ideals of the Republican state, the Catholic/Protestant Ethic and the spirit of capitalism social class language game, as their practical consciousness or those of the Vodou Ethic and the spirit of communism of the mass majority. Postmodern, post-structural, and postcolonial discourses are the language, ideology, and communicative discourse of post-industrial Catholic/ Protestant capitalist social relations of production recursively reorganized and reproduced by the Affranchis in the language of créolité, hybridity, indigénisme, négritude, double consciousness, etc., for equality of opportunity, recognition, and distribution with their former colonizers and slavemasters. That is to say, ambivalence, hybridity, liminality, créolité, négritude, double consciousness, etc., are the psychological processes, concepts, pathologies, and practical consciousness of the Affranchis bourgeoisies as they desire and struggle for equality of opportunity, recognition, and distribution with whites by reproducing their ideas and ideals as their practical consciousness in order to convict them (whites), amidst their racism and discrimination, for not identifying with their values and norms as revealed by black practices, i.e., practical consciousness. As though by highlighting their alleged ambivalence, double consciousness, négritude, and syncretism as opposed to the singular "African" otherness, reflected in the practical consciousness of the masses, which allowed for them to be discriminated against to start with, affords them, Affranchis, their desires (equality of opportunity, recognition, and distribution) and the sympathy of whites.

In other words, when the Haitian Revolution commences in 1791, there are three distinct groups (each interpellated by and socialized in different languages, ideologies, ideological apparatuses, etc.) vying for control of the island, the whites (blancs); free people of color and mulattoes (Affranchis), and the enslaved and escaped (maroon) Africans of the island. The latter, over sixty-seven percent of the population, were not a structurally differentiated other. They had their own practical consciousness, what Paul C. Mocombe [1] calls the "Vodou Ethic and the spirit of communism," by which they went about recursively (re)organizing and reproducing the material resource framework via the lakou system (Lakouism). The former two, free blacks and gens de couleur (Affranchis), were interpellated, embourgeoised, and differentiated by the language, communicative discourse, mode of production, ideology, and ideological apparatuses of the West and shared the same European practical consciousness, the Catholic/Protestant Ethic and the spirit of capitalism social class language game, as the whites. The latter social class language game stood against the Vodou Ethic and the spirit of communism social class language game of the majority of the Africans who were interpellated and ounganified/manboified by the language, communicative discourse, mode of production, ideology, and ideological apparatuses of oungan yo, manbo yo, gangan yo, and granmoun yo [1-3,7,9].

Be that as it may, four distinct Revolutions would come to constitute the Haitian Revolution: The Revolutions of the whites; mulattoes; creole blacks and former generals; and the Africans. The whites, were divided between large plantation owners, grand blanc, and petit-blancs, i.e., managers, slave drivers, artisans, merchants, and teachers [2]. The former, grand blanc, were independent-minded, and like the American colonists wanted political and economic independence from their mother-country, France, where their rights and economic interests were not represented in the National Assembly. The petit-blancs were more racist and feared the alliance between the larger landowners and the Affranchis. The Affranchis were free people of color and mulatto, gens de couleur, property and slave owners on the island who shared the religion, culture, language, and ideology of their white counterparts and wanted then Saint-Domingue to remain a French colony. Although internal antagonism based on race (color) and class existed between the free (creole) blacks and gens de couleur, I group them together under the nomenclature, Affranchis, to highlight the fact that their interpellation and embourgeoisement via the ideological apparatuses of the West rendered their practical consciousnesses identical even though there were racial/color (based on phenotype, not ideology) tensions between them (racial tensions, which still plaques Haiti today). Unlike the majority of white large plantation owners, however, the Affranchis, like Vincent Ogé, André Rigaud, Alexandre Pétion, Pierre Pinchinat, Toussaint Louverture, for examples, did not want independence from France. In the case of the mulattoes, who after independence would come to be referred to as the children of Alexandre Pétion, the first mulatto president of the Haitian Republic, they simply wanted their social, political, and economic rights recognized by France within the colony, not an independent nation-state or the end to slavery. In regards, to the children of Dessalines/Toussaint, creole slave drivers and free blacks, they sought equality of opportunity, recognition, and distribution vis-à-vis the whites and mulattoes. The enslaved and escaped Africans, the children of Sans Souci, of the island were divided between field slaves, domestic slaves, and 
maroons. The domestic slaves, like their African-American counterparts, "house slaves," more so identified with their slavemasters. However, for the most part, the field slaves and maroons, because of their relative isolation from whites, domestic slaves, gens de couleur, and free blacks, were interpellated and ounganified/manboified by the modes of production, language, ideology, ideological apparatuses, and communicative discourse of the Vodou Ethic and the spirit of communism, and many sought to reproduce their African ways of life in a national position of their own. In the end, the Revolution would come down to a struggle between the $A f$ franchis and the enslaved and maroon Africans of the island, the latter of whom commenced the Haitian Revolution on August $14^{\text {th }}, 1791$ at Bois Caiman and other congresses [1-3,7].

Following the Revolution, between 1804 and 1806, the purposive-rationality of the enslaved and maroon Africans would become a part of the modus operandi of the Haitian nation-state until October 17, 1806 when Jean-Jacques Dessalines, the founding father of the Haitian nation, was assassinated by Alexandre Pétion and Henri Christophe. At which point, the purposive-rationality of the Affranchis with their emphasis on integration into the mercantilist and free-trade dialectical logic of the global capitalist world-system, capitalist wealth, French culture, religion, and language became dominant at the expense of the African linguistic system, Kreyol; Vodou ideology; its ideological apparatuses; and modes of production, subsistence agriculture, husbandry, and komes, of the African masses on the island who took to the mountains and provinces following the death of Dessalines [2,3]. This is not to say that Dessalines completely sided with the purposive-rationality or practical consciousness of the African masses who sought to recursively reproduce their Vodou Ethic and spirit of communism, i.e., subsistence agriculture, husbandry, and komes (commerce), practical consciousness on the island via the lakou system. The argument here is that via his nationalization project, he attempted to balance the purposive-rationality of his grandon class of former generals and slave drivers, i.e., the creole blacks, who yearned to become wealthy landowners and masters like the whites and racist mulatto elites amidst the desires of the African masses seeking to reproduce their subsistence agriculture, husbandry, and komes. Be that as it may, the internal struggles between the two bourgeoisies within the Affranchis, the mulatto elites who controlled the export/import trade and the free blacks who controlled the land and agribusinesses where the African masses toiled as cultivators, over control of the state and its ideological apparatuses would dominate the political and economic conditions of post-revolution Haiti to the present at the expense of the practical consciousness of the African masses $[2,3,7,8]$. Both groups would arm the youth and peasants of the island to achieve their initiatives, i.e., control of the state and its ideological apparatuses. Today, under the neoliberal guise of Western powers, the latter, grandon class, composed of educated professionals, former drug dealers, entertainers, and police officers (mercantilists or protectionists) attack the former (free-trading) Affranchis class, which is now a comprador bourgeoisie seeking to build, own, and manage hotels and assembly factories producing electronics and clothing for the US market, under the moniker the chil- dren of Jean-Jacques Dessalines against the children of Alexandre Pétion in the name of the African masses of the island, the majority of whom are peasant farmers (the children of Sans Souci and Macaya, i.e., Congolese leaders of the Revolution who wanted no part of the capitalist world-system) seeking to recursively (re)organize and reproduce the lakou system and the Vodou Ethic and the spirit of communism as their form of system and social integration against the Protestant Ethic and spirit of capitalism.

\section{Conclusion}

Haiti's educational problematic rests on the fact that the elites (petit-bourgeois blacks, mulatto elites, and Arabs) have attempted to interpellate and embourgeois the African masses to participate in the global capitalist world-system of the Europeans as laborers against the attempt to reproduce the lakouism and Vodou Ethic and the spirit of communism of the former group who are the majority. This has led to a mismatch of linguistic structure and social class function between the two forms of system and social integration. Whereas early on in the history of the nation-state the emphasis of the elites was on an educational system, for the elites who governed the country, based on the French and Catholic models heavily geared towards literature, the arts and humanities, and foreign languages with French as the language of instruction $[3-5,11]$. When the US occupied (1915-1934) the country they sought, based on what they did for the black Americans with the establishment of Historically Black Colleges and Universities (HBCUs) as technical, agricultural, and mechanical schools following the American Civil War, to constitute the educational system of the island around technical and mechanical training for the masses so that they can fulfill their labor roles as a periphery nation-state producing agricultural and manufacturing productions for the First World or core states. Following the occupation, the Haitian elites, for the most part, returned to their French model, in defiance of the US, at the expense of technical training and the hardcore sciences, i.e., physics, etc., with French as the language of instruction [11]. The Africans in the mountains and provinces either relied on the Catholic Church for their education (predominantly in French), or the oral traditions, herbal knowledge, and ideologies of the lakous under Vodou priest and priestesses (oungan and manbo) transmitted (orally) via Kreyol as the medium of communications and instructions.

As a result of this socio-history, contemporarily, the Haitian educational system is constituted as a three-tier system. The first tier is based on the French and Catholic models directed towards the education of the elites with instruction in French. The emphasis in this tier is on literature, foreign languages, law, and the humanities and arts. The second tier is based on the American model of vocational and technical training with instruction also taking place in French so as to facilitate the role of the masses as technical, agricultural, and mechanical laborers for global capital. Albeit, there is a push for Kreyol instruction in the early stages of this latter tier as was the case somewhat under the American occupation. The third tier is based on Vodou, herbal medicine, and the oral traditions of the Africans with instruction solely in Kreyol under the control of Vodou priest and priestesses in the moun- 
tains and provinces of the country. This latter model is less formal than the former two under the control of the state, church, and NGOs, and emphasizes the pawol, spoken language of the masses, for instruction and practices.

In my view, in order for the Haitian educational system to truly be liberating from the exploitative (neoliberal) logic of the elites, the emphasis should be twofold: institutionalizing the lang (formal) grammar of the Kreyol language as the medium of and for instruction; and provide training in physics, psychology and medicine, and the general (physical and earth) sciences (via the grammar of Kreyol as the language of instruction) for the reproduction of the mode of production, which should be tied to the sustainability of the human being and the material resource framework of the island as highlighted in the lakou system of the Africans of the provinces and mountains. This latter work is the intent of the Haitian Initiative coming out of the Massachusetts Institute of Technology (MIT) under the direction of Michel DeGraff [5], the Haitian Academy of Kreyol, which seeks to formalize the Kreyol language for schooling, scientific research, and legal integration of the society, and Mocombe's Kreyol Reading Room Series, which systematize the Kreyol language via its generative grammar.

\section{References}

1. Mocombe Paul C (2016) The vodou ethic and the spirit of communism: The practical consciousness of the African people of Haiti. University Press of America, Maryland.
2. Du Bois Laurent (2004) Avengers of the new world. Harvard University Press, Massachusetts.

3. Du Bois Laurent (2012) Haiti: The afterschocks of history. Metropolitan Books, New York.

4. Dejean Yves (2010) Creole and education in Haiti. In: Arthur K Spears, Carole Berotte Joseph, The Haitian Creole language: History, structure, and use and education. Lexington Books, New York.

5. DeGraff Michel (2010) Language barrier: Creole is the language of Haiti, and the education system needs to reflect that. The Boston Globe.

6. Mocombe Paul C (2019) The theory of phenomenological structuralism. Cambridge Scholars Publishing, Newcastle upon Tyne, UK.

7. James CLR (1986) The Black Jacobins: Toussaint L' Ouverture and the San Domingo revolution. Vintage.

8. Buck-Morss Susan (2009) Hegel, Haiti, and Universal History. University of Pittsburgh Press, Pittsburgh.

9. Ramsey Kate (2011) The spirits and the law: Vodou and Power in Haiti. University of Chicago Press, Chicago.

10. Mocombe Paul C (2018) Mind, body, and consciousness in society: Thinking Vygotsky via Chomsky. Cambridge Scholars Publishing, Newcastle upon Tyne, UK.

11. Robertshaw Matthew (2018) Occupying Creole: The crisis of language under the US occupation of Haiti. The Journal of Haitian Studies 24: 4-24.

DOI: $10.36959 / 763 / 515$ 